\title{
The Effect of Teacher Teaching Skills Against Learning Outcomes
}

\author{
Universitas Negeri Jakarta \\ yadisumyadi@yahoo.co.id
}

Yadi Sumyadi, Umasih, Abdul Syukur

\author{
Article History \\ accepted 1/09/2020
}

approved 4/10/2020

published $1 / 12 / 2020$

\begin{abstract}
Learning outcomes have an important role in the learning process. This is because learning outcomes can be used as a benchmark to find out how far the students have changed after receiving their learning experiences, observed and measured in the form of knowledge, attitudes and skills. Learning outcomes are often used as a measure to determine how far a person has mastered the material that has been taught. So, learning outcomes are abilities that students achieve after going through the learning process to determine mastery of the material that has been taught. The problem in this study is that most students still consider history lessons to be limited to memorizing so that they are less interested in history lessons. This can be a measure of the level of understanding of students towards certain materials that have been given. The purpose of this study was to determine how much influence the teaching skills of teachers have on student learning outcomes. The research method used in this research is ex post facto, which means after the fact, by taking survey data. The population and sample in this study were students at SMA Perguruan Rakyat 2 East Jakarta.
\end{abstract}

Keywords : Teaching skills, learning outcomes

\begin{abstract}
Abstrak
Hasil belajar mempunyai peranan penting dalam proses pembelajaran. Hal ini disebabkan karena hasil belajar dapat dijadikan tolak ukur untuk mengetahui seberapa jauh perubahan pada diri siswa setelah menerima pengalaman belajarnya yang didapat, di amati dan diukur dalam bentuk pengetahuan, sikap dan keterampilan. Hasil belajar seringkali digunakan sebagai ukuran untuk mengetahui seberapa jauh seseorang menguasai materi yang sudah diajarkan. Jadi, hasil belajar merupakan kemampuan yang dicapai siswa setelah melalui proses belajar untuk mengetahui penguasaan materi yang telah diajarkan. Permasalahan dalam penelitian ini adalah sebagian besar siswa masih menganggap pelajaran sejarah hanya sebatas hapalan sehingga kurang meminati pelajaran sejarah. Hal ini dapat menjadi tolak ukur dari tingkat pemahaman peserta didik terhadap materi tertentu yang telah diberikan. Tujuan dari penelitian ini adalah untuk mengetahui apakah ada pengaruh keterampilan mengajar guru terhadap hasil belajar siswa. Metode penelitian yang akan digunakan dalam penelitian ini adalah ex post facto yang artinya sesudah fakta, dengan pengambilan data secara survey. Populasi dan sampel dalam penelitian ini adalah siswa di SMA Perguruan Rakyat 2 Jakarta Timur.
\end{abstract}

Kata Kunci : Keterampilan mengajar, hasil belajar

Social, Humanities, and Education Studies (SHEs): Conference Series https://jurnal.uns.ac.id/shes

p-ISSN 2620-9284

e-ISSN 2620-9292

This work is licensed under a Creative Commons Attribution-ShareAlike 4.0 International License. 


\section{PENDAHULUAN}

Hasil belajar mempunyai peranan penting dalam proses pembelajaran. Hal ini disebabkan karena hasil belajar dapat dijadikan tolak ukur untuk mengetahui seberapa jauh perubahan pada diri siswa setelah menerima pengalaman belajarnya yang didapat diamati dan diukur dalam bentuk pengetahuan, sikap dan keterampilan. Rusman (2015:67), mengatakan bahwa hasil belajar adalah sejumlah pengalaman yang diperoleh siswa mencakup ranah kognitif, afektif dan psikomotorik Selain itu Hamzah B.Uno (2010: 213), berpendapat bahwa hasil belajar adalah perubahan perilaku yang relatif menetap dalam diri seseorang sebagai akibat dari interaksi seseorang dengan lingkungannya.

Mutu Pendidikan dapat dilihat dari hasil belajar siswa. Menurut Purwanto (2011:44), hasil belajar seringkali digunakan sebagai ukuran untuk mengetahui seberapa jauh seseorang menguasaibahan yang sudah diajarkan. Jadi, hasil belajar merupakan kemampuan yang dicapai siswa setelah melalui proses belajar untuk mengetahui penguasaan materi yang telah diajarkan. Hal ini dapat menjadi tolak ukur dari tingkat pemahaman peserta didik terhadap materi tertentu yang telah diberikan.

Belajar sejarah memiliki peran penting terhadap pembangunan peradabana bangsa Indonesia. Sejarah adalah mata pelajaran yang menekankanpengetahuan dan nilai - nilai mengenai proses perubahan dan perkembangan masyarakat dari masa lalu hingga masa sekarang. Berdasarkan manfaat yang diperoleh dengan mempelajari sejarah semestinya mata pelajaran sejarah merupakan mata pelajaran yang sangat penting untuk dipelajari, menarik, menyenangkan dan tidak membosankan. Tetapi pada kenyataannya di sekolah - sekolah tidaklah demikian, mata pelajaran sejarah cenderung diremehkan dan kurang diminati oleh siswa karena beberapa diantaranya pelajaran sejarah yang membosankan, kurang menarik, dan cenderung membuat siswa gaduh ataupun mengantuk, sehingga pelajaran sejarah tidak dapat berfungsi sebagaimana mestinya.

Faktor yang menyebabkan rendahnya hasil belajar siswa pada mata pelajaran sejarah di SMA Perguruan Rakyat 2 Jakarta yaitu diduga keterampilan mengajar guru dan minat belajar yang rendah. Sasmita Hairia (2014: 15) menyatakan bahwa ketika memulai pembelajaran guru sejarah kurang memperhatikan persiapan mental dari siswa yang akan menerima materi pelajaran sejarah, guru terkadang tidak mengawali pelajaran dengan memberikan gambaran tentang materi yang akan dipelajari tetapi langsung ke inti materinya sehingga siswa sulit memahami pelajaran dan ketika mengakhiri pelajaran, terkadang guru langsung menutup pelajaran tanpa melakukan evaluasi terlebih dahulu.

Guru sangat menentukan hasil belajar siswa karena guru merupakan sutradara sekaligus aktor dalam proses pengajran yang nantinya akan mempengaruhi hasil belajar siswa. Selain itu, guru yang secara langsung membimbing, membantu, mempengaruhi, dan mengembangkan potensi yang ada pada diri siswa mencapai tujuan. Hal ini sesuai dengan pendapat Uno (2008:17) yang menyatakan bahwa seorang guru sangat berpengaruh terhadap hasil belajar yang ditunjukan oleh peserta didiknya.

Berdasarkan pengamatan peneliti di SMA Perguruan Rakyat 2 Jakarta Timur,keterampilan mengajar guru sejarahmasih harus diperhatikan terkadang dalam proses pembelajaran sejarah di dalam kelas guru masih bersifat teaching center, guru masih menjadi pusat atau central dalam proses pembelajaran sehingga kecenderungan guru masih dominan dalam pembelajaran.

Guru masih kurang memiliki keterampilan mengajar dalam hal menggunakan variasimetode dan model pembelajaran. Guru masih kecenderungan menggunakan metode ceramah dalam memberikan materi. Guru belum dapat menjadi tutor sebaya yang baik dan mentor dalam diskusi kelompok dan guru masih teks book oriented sehingga belum dapat mengaitkan materi sejarah dengan kehidupan sehari-hari, sehingga siswa cenderung kurang perhatian dan mudah merasa bosan, yangberdampak 
pada hasil belajar sejarah yang belum maksimal dan memuaskan. Perlu adanya pengoptimalisasian keterampilan mengajar guru dalam proses pembelajaran sehingga dapat menumbuhkan minat belajar sejarah yang baik sehingga hasil belajar sejarah yang didapatkan menjadi lebih baik.

Keterampilan mengajar guru sejarah yang baik dapat mendorong siswa menjadi lebih mudah memahami dan menerima pelajaran sejarah sehingga dapat menggembangkan pengetahuan dan nilai - nilai terkait dengan peristiwa - peristiwa sejarah yang terdapat dalam materi pelajaran yang memiliki korelasi dengan kehidupan hari ini.

Berkaitan dengan hal tersebut, maka peneliti merasa perlu untuk melakukan penelitian untuk melihat apakah terdapat pengaruh keterampilan mengajar guru dan minat belajar terhadap hasilbelajar Sejarahdi SMA Perguruan Rakyat 2 Jakarta Timur.

\section{METODE}

Metode penelitian yang akan digunakan dalam penelitian ini adalah ex post factoyang artinya sesudah fakta, dengan pengambilan data secara survey. Penelitian ex post factomerupakan penelitian yang bertujuan menemukan penyebab yang memungkinkan perubahan perilaku, gejala atau fenomena yang disebabkan oleh suatu peristiwa, perilaku atau hal - hal yang menyebabkan perubahan pada variable bebas yang secara keseluruhan sudah terjadi (Sukardi, 2003: 174)

Pengeritian yang lebih khusus bahwa penelitian ex post factoadalah penelitian yang dilakukan sesudah perbedan - perbedaan dalam variable bebas terjadi karena perkembangan suatu kejadian secara alami (Furchan,2002 : 383). Penelitian ex post facto merupakan penelitian dimana variable bebas telah terjadi Ketika peneliti mulai dengan pengamatan variable terikat dalam suatu penelitian. Penelitian ex post factoatau penelitian kausal komparatif berarti penelitian dimana peneliti berusaha menentukan penyebab atau alasan, untuk keberadaan perbedaan dalam perilaku atau status dalam kelompok individu.(Sukardi, 2008 : 165).

\section{a. Analisis instrumen}

\section{HASIL DAN PEMBAHASAN}

Instrumen yang digunakan dalam penelitian ini telah memenuhi persyaratan dan analisis selanjutnya pada tingkat kesukaran dan daya pembeda soal sudah memenuhi sebagai instrumen. Uji hubungan dan pengaruh dalam penelitian ini akan dilakukan uji regresi dengan menggunakan SPSS 16.

b. Deskripsi hasil penelitian

Data yang digunakan pada penelitian ini adalah hasil belajar siswa serta data hasil observasi keterampilan mengajar guru pada proses pembelajaran. Data hasil belajar dan keterampilan mengajar guru sebagai berikut:

1) Hasil belajar Adapun hasil belajar yang diperoleh nilai rata-rata (mean) $=82,9091$ dan standar deviasi (standar deviation) $=5,95742$.

2) Keterampilan mengajar guru, adapun nilai rata-rata (mean) dari keterampilan mengajar guru $=86,4545$ dan standar deviasi keterampilan mengajar guru $=$ 6,34608. 3) Uji hipotesis

Analisis data dengan menghitung koefisien korelasi dan uji signifikannya kemudian dilanjutkan dengan menentukan persamaan regresinya, dalam perhitungan penelitian ini menggunakan SPSS 16 agar dapat mengetahui hubungan kemampuan berpikir kreatif terhadap hasil belajar siswa dan pengaruh kemampuan berpikir kreatif terhadap hasil belajar siswa. 
Tabel 1. Uji Validitas data keterampilan mengajar gruru dan hasil belajar.

\begin{tabular}{lll} 
& $\begin{array}{l}\text { Keterampilan mengajar } \\
\text { guru }\end{array}$ & Hasil Belajar \\
& & \\
\hline $\begin{array}{l}\text { Keterampilan mengajar } \\
\text { guru }\end{array}$ & 1 & 475 \\
$\mathrm{~N}$ & 26 & 140 \\
& & 26 \\
& & \\
Hasil belajar & 475 & 1 \\
$\mathrm{~N}$ & 140 & 26 \\
& 26 & \\
\hline
\end{tabular}

Signifikan hasil korelasi

Hipotesis: HO : Ada hubungan antara keterampilan mengajar guru dan hasil belajar siswa.

$\mathrm{Ha}$ : Ada hubungan antara keterampilan mengajar guru dan hasil belajar.

Dasar pengambilan keputusan: Jika probabilitasnya $>0,05$ maka H0 diterima Jika probabilitasnya $<0,05$ maka $\mathrm{H} 0$ ditolak Diperoleh $\alpha=0,140>0,05$ sehingga $\mathrm{H} 0$ diterima. Jadi, ada hubungan antara keterampilan mengajar guru terhadap hasil belajar siswa.

Kesimpulan: Koefisien korelasi yang ditemukan signifikan, yaitu dapat digeneralisasikan ke seluruh sampel yang diambil.

Tabel 2. Uji Pengaruh Kemampuan Keterampilan Mengajar Guru Terhadap Hasil Belajar.

\begin{tabular}{|c|c|c|c|c|c|}
\hline Model & $\begin{array}{l}\text { unstano } \\
\text { coefficie } \\
\text { B } \\
\text { error }\end{array}$ & $\begin{array}{l}\text { diced } \\
\text { std. }\end{array}$ & $\begin{array}{l}\text { Standardiced } \\
\text { Beta }\end{array}$ & $\mathrm{t}$ & sig \\
\hline Constant & 44.533 & 25.972 & & 1.715 & .121 \\
\hline $\begin{array}{l}\text { Keterampilan } \\
\text { mengajar guru }\end{array}$ & .506 & .313 & .475 & 1.618 & .140 \\
\hline
\end{tabular}

Pada tabel diatas dapat menunjukkan persamaan regresi dari variabel keterampilan mengajar guru dan hasil belajar siswa. Diperoleh persamaan regresi $Y=44,533+0,506$ $x$, artinya setiap penambahan variabel keterampilan mengajar guru sebesar satu satuan, maka variabel hasil belajar mahasiswa bertambah sebesar 0,506 satuan.

\section{SIMPULAN}

Berdasarkan hasil dan pembahasan, Hipotesis: $\mathrm{HO}$ : Ada hubungan antara keterampilan mengajar guru dan hasil belajar siswa. Ha : Ada hubungan antara keterampilan mengajar guru dan hasil belajar. Dasar pengambilan keputusan: Jika probabilitasnya > 0,05 maka $\mathrm{HO}$ diterima Jika probabilitasnya $<0,05$ maka $\mathrm{H} 0$ ditolak Diperoleh $\alpha=0,140$ $>0,05$ sehingga $\mathrm{HO}$ diterima. Jadi, ada hubungan antara keterampilan mengajar guru terhadap hasil belajar siswa. Koefisien korelasi yang ditemukan signifikan, yaitu dapat digeneralisasikan ke seluruh sampel yang diambil. Maka dapat ditarik kesimpulan bahwa Terdapat pengaruh antara keterampilan mengajar guru terhadap hasil belajar siswa 


\section{DAFTAR PUSTAKA}

Aytekin Isman, Fahad Abdulaziz Abanmy. 2012. Using Blended Learning In Developing StudentTeachersTeaching Skills. Tojet: The Turkish Online Journal Of Educational, 336 - 345

Bruce A Vansledright. 2010. And Santayana Lives on : Students' views on the purposes for studing American History. Journal of Curriculum Studies, 29:5, 529-55, DOI : 10.1080/002202797183892

Cosme J. Gómez Carrasco1, Pedro Miralles Martínez. 2016. Historical Skills In Compulsory Education: Assessment, InquiryBased Strategies And Students' Argumentation.New Approaches In Educational Research. Doi: 10.7821/Naer.2016.7.172

Marwoto. Strategi guru sejarah dalam meningkatkan minat belajar siswa pada mata pelajaran sejarah di SMAN 10 Pekanbaru. Jurnal ilmu -ilmu sejarah, budaya dan sosial, $26-31$

Purwanto, N. (2008). Prinsip-prinsip dan teknik evaluasi pengajaran. Bandung : CV. Remaja Karya.

Rusman. (2015). Pembelajaran Tematik Terpadu : Teori, Praktik dan Penilaian. Jakarta : Rajawali Pres

Sabri. (2003). Psikologi pendidikan dan evaluasi pendidikan. Jakarta : Gramedia

Slameto. (2010). Belajar dan faktor-faktor yang mempengaruhinya. Jakarta: Rineka Cipta

Sasmita Hairia.dkk (2014). Pengaruh Keterampilan Mengajar Guru terhadap Motivasi Belajar Siswa pada mata pelajaran IPS terpdu di kelas IX MTs Negeri Bolangitang Timur. Jurnal Universitas Negeri Gorontalo. Vol. 2, No. 1

Young jun Dan, Reese Todd. 2014. Examining the mediating effet of learning strategies on the relationship between students' historu interest and achievement.Education Psychology, 799-817 